\title{
Power, luck and ideology -- technological and institutional parameters of the agency problem for CEOs ${ }^{1}$
}

\author{
by \\ Peter Skott ${ }^{2}$ and Frederick Guy ${ }^{3}$ \\ Preliminary version, December 2012
}

\begin{abstract}
:
The microprocessor and related technologies have transformed the information systems in the late twentieth century with profound effects on the relative power of different groups. Skott and Guy (2007) and Guy and Skott (2008) formalized one aspect of this process of power-biased technical change: firms' increased ability to monitor low-paid employees and the resulting changes in inequality and employment at the low end of the income distribution. This paper addresses power biases and income inequality at the high end. The explosion of pay to top managers is best understood, we argue, as a result of increasing volatility (uncertainty) of the general business environment and an associated intensification of the agency problem: the power of corporate executives has increased. Institutional changes -- including changes in ideology and pay norms -- affect power and have contributed to the explosion in executive compensation.
\end{abstract}

JEL numbers: J31, 033

Key words: communications technology, power-biased technical change, inequality, CEO compensation, efficiency wage.

\footnotetext{
${ }^{1}$ Paper prepared for the ASSA meetings, San Diego, January 2013.

${ }^{2}$ Department of Economics, University of Massachusetts, Amherst, MA 01003, USA; pskott@econs.umass.edu.

${ }^{3}$ Department of Management, Birkbeck, University of London, Malet St, London WC1E 7HX, UK; f.guy@bbk.ac.uk
} 


\section{Introduction}

Why has the pay of CEOs exploded over the past several decades? We argue that new technologies and shorter product life cycles have changed market structure, and through market structure the shareholder-CEO agency problem, leading to a rise in pay. We caution, however, that these effects of technology on market structure and top pay are institutionally contingent.

A growing strand of literature explains CEO pay as market-based and efficient. Gabaix and Landier (2008), for example, attribute the explosion to the market for scarce talent, combined with a parallel explosion in the market value of corporations. One obvious problem with that analysis is that it ignores agency - a central question in the pay of CEOs since the work of Jensen and Meckling (1976), and Jensen and Murphy (1990). Another is that CEO pay has not always been so tied to market value. Before the explosion, pay at the top was a relatively steady function of pay on the bottom of the same companies (Simon 1957; Guy 2005); attributing the rise in pay to the rise in market valuation does not tell us why the two came to be tied together. Perhaps we should attribute the rise in CEO pay - and the rise in inequality generally - primarily to institutional change, as Atkinson (2000), DiNardo et al (1996), and Levy and Temin (2007) do. Even if this is true, it is somewhat unsatisfying to treat a large set of institutional changes - what we can call neo-liberalism - as exogenous.

We can, more reasonably although with necessary caveats, treat technological change as exogenous. There is a large body of research linking changes in the distribution of income to changes in technology. Most of this literature focuses on technology as a determinant of the demand for skill, and attributes increased earnings inequality in recent decades to skill-biased technological change following the introduction of modern information and communication technologies (ICTs; for an overview see Card and DiNardo 2002, Autor et al. 2008). In earlier work, we have argued that this line of reasoning neglects the role of technology in both monitoring and planning work: technological change can alter the parameters of the agency problems. The parameters are affected differently for different groups of workers; some may lose power and others gain, with power meaning the ability to make choices which affect the company's profitability. We call this power-biased technological change (PBTC); (Skott and Guy 2007; Guy and Skott 2008, 2008a).

In this paper we make a parallel argument with regard to CEOs. The importance of agency problems for the pay of top executives should not be controversial, given both the voluminous literature on the 
issue and the belief by compensation committees that the problems are critical. When the relationship between CEO pay and technological change are discussed, however, agency problems tend to be ignored; implicitly the analysis excludes effects of technological change on the severity of the agency problems. This exclusion is unfounded.

New technologies have aggravated the agency problem for CEOs by changing the structure of markets. They have done this in two ways. First, ICTs have, accentuated markets' winner-take-all (WTA) characteristics; second, both WTA markets, and a reduction in product life cycle time (von Braun 1990; Kurzweil 1992), contribute to an increase in firm-level volatility (Comin and Mulani 2006; Chun et al. 2008). WTA means that greater consequences ride on the choices made by CEOs; firm-specific volatility exacerbates the information asymmetry between CEOs and shareholders. Thus, both WTA and volatility change the parameters of the agency problem. The result -- using standard agency arguments -- is a rise in CEO pay. Ideological shifts and changing norms of fairness have contributed to the rise in pay. The changes in market structure also change the normative framework within which CEOs work. The volatility of firm level outcomes and the greater mobility of CEOs reduce attachment to employees; paying CEOs as if they were capitalists helps increase social separation between them and their subordinates, and increases identification (as well as incentive alignment) with their principals. On balance, these changes, we argue, accentuate the agency problem and contribute to the rise in the pay of CEOs. ${ }^{4}$

Our focus on technology and the principal-agent problem should not be seen as a denial of the importance of the institutional framework. ICTs create WTA markets because the state allows them to. Formal institutions create the framework within which, for instance, network products or intellectual property produce a WTA outcome. Competition policy, intellectual property law, labor market institutions, corporate governance institutions, and the tax system all affect the distribution of gains within a given product market structure, and also affect the incentives to shape product markets in particular ways. We are not saying, then, that the problem should be understood as one of technology

\footnotetext{
${ }^{4}$ Our approach helps explain not only the rise in pay of CEOs, but of any agent responsible for strategic decisions affecting corporate ownership or investment; critically, it applies to people involved in those choices from outside the corporation, such as investment bankers: both CEOs and investment bankers are decision makers with important private information in uncertain markets. Note also that we are explaining increases in earnings (salaries and business income); as Piketty and Saez (2003) show, the increased income share of the top $0.1 \%$ has, in the US, been primarily from those sources - in marked contrast to the top echelon's previous dependence on property income.
} 
rather than institutions; we are saying that the institutional problem needs to be understood as one of choosing how to regulate markets, given a particular technological endowment.

Section 2 describes important changes in technology and their effects on volatility and the winnertake-all properties. Section 3 considers interactions between technological and institutional factors. Section 4 presents a formal model of CEO pay. The analysis of a benchmark version based on Shapiro and Stiglitz (1984) is followed by extensions that incorporate social norms and ideology. Chapter 5 concludes.

\section{New technology, winner-take-all, and volatility}

The new ICTs produce WTA markets in two ways. First, they improve the codification of knowledge, with the effect of accentuating increasing returns in production. Second, they facilitate the modularization of production, allowing the isolation of rents and quasi-rents in firms located at strategic positions along supply chains; these firms often have relatively few employees. The WTA structure of markets, together with shorter product life cycles, helps explain the rise in firm-specific volatility.

\subsection{Codification}

Codification can be understood as the process of turning knowledge into information or, in other terms, making tacit knowledge explicit: it puts some knowledge in a standard form (a code), which makes it easier to communicate, to re-use, or to share the knowledge. Codification has been an important element in the advance of the organization of production. An important example comes from the standardization of production methods and the creation of interchangeable parts (Hounshell 1984). Other examples include the ability to incorporate such instructions in computer programs, or the ability to manipulate the genetic code.

New applications of codification in production often become sources of increasing returns: codification is costly, and results in a set of instructions which reduce the marginal cost of production. The marginal cost of production at any scale is trivial in comparison to the average cost in what we can term pure information products: for example, digitized music, film, and games; general purpose, or shrink-wrapped, software, such as Microsofts's Office and Windows; and genetically modified 
organisms. Beyond these extreme cases, the costs of designing products and processes have risen while the marginal costs of production have fallen for many manufactured goods and services.

Codification facilitates the establishment of technical standards employed in both the creation and the use of many goods and services, generating further increasing returns through a network effect. When the replicable code and/or the technical standard are proprietary or special purpose, they create private increasing returns and winner-take-all markets.

\subsection{Modularity: outsourcing, offshoring, and corporate parts}

ICTs (here we include transport technologies, such as container freight and air travel, along with communications) also facilitate the geographical dispersal of production activity -- up to and including offshoring. Offshoring and outsourcing (in common with any production collaboration over distance) depend on transport and communications; communications, in turn, depend not only on the ability to send a message, but the codification of the content of that message in a way that it is usable to people at the other end. Technological advances have made it possible to do outsourcing on a modular basis -that is, with technological and contractual details sufficiently well codified that business in a highly interdependent supply chain can be conducted on an arm's length (Sturgeon 2002).

The ability to separate elements of supply chains in corporate organizational, spatial and -- in the

case of offshoring -- jurisdictional terms may be one of the drivers of overall earnings inequality (Spence and Hlatshwayo 2011). In the early years of the current wave of inequality, at least, between-firm earnings dispersion in US manufacturing rose far more than within-firm dispersion did (Juhn et al. 1993). Generally, earnings differentials within organizations are lower than what we would expect for the same individuals in the market (Frank 1985), and this tendency interacts with increasing modularity.

Modularity makes it possible to isolate a source of rents -- what are, in the language of business strategy, sources of "sustainable competitive advantage" (Porter 1985), the "core competencies" of the organization (Prahalad and Hamel 1990) -- limiting the pool of people who are able to exercise some claim on a share. This helps explain the particularly steep rise in between-firm wage inequality (Card et al. 2012; Juhn et al. 1993). 
Modularity also fuels the market for corporate control, by creating smaller and more internally homogenous corporate elements for which there is a readier market -- a sort of market in company parts. $^{5}$

\subsection{WTA, technological change and volatility}

Firm-level volatility is, by definition, idiosyncratic, unexplained by cyclical factors or industry trends. During the 'great moderation' of the late 1980s and 1990s, many aggregate measures saw reduced volatility, while firm-level volatility (the residual after controlling for aggregate volatility) grew. This was first established with regard to the volatility of stock prices (Campbell et al. 2001; Wei and Chu 2006). It is now clear that the same trend applies to fundamentals such as growth of sales, profits, employment, investment, and TFP (Comin and Mulani 2006; Chun et al. 2008; Chun et al. 2010; Comin et al. 2010); firm-level volatility of these measures increased steadily between 1970 and the mid 2000s, then fall slightly.

Different explanations have been offered for the rise in idiosyncratic volatility. Brandt et al (2010) attribute stock market volatility to a larger proportion of ill-informed traders during speculative bubbles, but this is inconsistent with the duration of the growth of idiosyncratic volatility, and more critically with the observed volatility in fundamentals. Others tie volatility to new technology, either through uneven experiences with the adoption of technology (Chun et al. 2010), or uncertainty in the firm's market for its own technology (Comin et al. 2009; Pástor and Veronesi 2009). The latter is consistent with WTA markets, and also with the common observation that product life cycles have become shorter (von Braun 1990; Kurzweil 1992).

For our purposes, the important point is that idiosyncratic volatility -- uncorrelated differences in firm performance, not explicable with public information -- presents a problem of information asymmetry. The CEO may have private information as to whether a bad performance by the firm was unavoidable, or the result of the CEO's poor judgment or poor effort. But as volatility grows, owners face an increasing risk of dismissing CEOs for bad performance when the bad performance was outside their control or, conversely, retaining poor CEOs when good performance came as a result of pure luck.

\footnotetext{
${ }^{5}$ Another factor may be dis-agglomerization; a law of large numbers with well-performing divisions making up for the poor performance of others no longer operates to same extent at the firm level.
} 


\section{Technological and institutional determinants of CEO pay}

We claim that applications of new ICTs produce WTA markets; that WTA and short product life cycles together produce volatility; and that, between them, these change agency relationships in a way that benefits top corporate executives and their Wall Street counterparts. This might seem a tidy bit of technological cause-and-effect, but before moving on to show how WTA markets and technological volatility produce high CEO pay, we need to qualify our claim by noting that both WTA markets and much of the associated volatility exist not only because of technology but because they have been allowed to.

\subsection{Institutional contingency}

Consider four examples: network effects, monopoly due to intellectual property rights, modularity, and the market for corporate control.

\section{Network effects}

Many markets created by new ICTs have WTA properties because of network effects: Google's domination of Web advertising, Microsoft's domination of personal computer operating systems and standard productivity applications, Amazon's domination of certain on-line retail markets, and so on (the examples continue in any smaller, more specialized, market: does anyone you know use Endnote, Stata, or Blackboard?). Such market domination has a technological face, but it also has an obvious regulatory one: Microsoft's position has been hard fought with courts and regulators in many countries for many years, and rests not on the substance of its products, but on the slender reed of being allowed to control certain application program interfaces (APIs), such as document formats. In a regulatory regime where such interfaces are public property, software markets would have very low entry barriers, and could function largely as markets for customization and service (Stallman 1985; Raymond 1998).

The institutional contingency of technologically facilitated network monopolies is also apparent in one that has not happened: despite persistent lobbying by internet service providers (ISPs) for the right to prioritize content as they choose, in the case of the Internet (unlike, say, the case of cable TV, which often goes down the same wires) 'net neutrality' has been largely maintained in the US. This represents 
the continuation, and adaptation to a new technology, of the common carrier principle, a legacy of earlier generations of network regulation.

\section{Intellectual property rights}

Even absent network effects, WTA markets can be created by the structure of intellectual property rights (IPRs). In recent decades, IPRs have been extended through legislation, court decisions, and treaties (Sell and May 2001): new categories have become patentable (genetic code, software); broader patent claims are allowed, making it harder for competitors to 'invent around' a patent (Freeman 1995); pharmaceutical companies are permitted to leverage their patent rights with a variety of legal protections both from international trade and from sensible public procurement; the copyright doctrine of fair use is undermined by the rental model for digital media; internationally, the TRIPS treaty makes intellectual property protections more uniform and enforceable; IPR rights are commonly extended beyond the TRIPs provisions by bilateral agreements between the US or EU and their smaller trading partners. Thus, although codified information makes up more of what we buy than it once did, it would be incorrect to say that this technological fact creates, or necessitates, the expansion of IPR monopolies (Boldrin and Levine 2008).

\section{Modularity}

The ability to exploit modularity creates consequential choices for the CEO, involving private information and uncertain outcomes. Yet, again, there are a number of ways in which a different institutional environment might constrain these choices: they are fueled by the trade policy (not only the reduction of trade barriers, but a range of tax subsidies to investment in new jurisdictions and locations), by a capital market highly tolerant of leverage, and in particular by weak protections for employment, wage rates, pension rights, and union representation, all of which make it easier to exploit modularity for purposes of cost reduction.

\section{Financialization}

The fact that financial deregulation is associated with dramatically higher salaries in the financial sector is well documented (Philippon and Reshef 2008). The rise of pay on Wall Street is linked with the simultaneous rise pay of CEOs (Kaplan and Rauh 2010) by more than coincident instances of regulatory dereliction. Financial deregulation was part of what is often called the financialization of the economy, which in the present case has two salient characteristics. One is a high tolerance for risk, on the part 
both of regulators and investors, in a way consistent with the Minsky-Kindleberger model (Minsky 1975). The other is the elevation of shareholder value to its place as the overriding and central responsibility of corporate directors. The latter gained support from the movement of pension funds into securities markets (O'Sullivan 2001), which created a mass political constituency for the principle of maximizing shareholder value. (We should note here that one factor encouraging this development was the growth of firm- and industry-level volatility, which made it less acceptable to keep pension obligations on a company's own books; countries where most pensions were delivered by publically managed pay-as-you go systems largely escaped both the move of pensions to the market, and the elevation of shareholder value maximization to the status of major public virtue (Gourevitch and Shinn 2005)). High leverage and the principle of shareholder value gave bankers and executives the means and the motive for creating an active market for corporate control - which includes, as noted in our discussion of modularity, a market for corporate parts. While this market has in the past been praised as offering a tidy solution to the principal-agent problem (Jensen 1989), we want to emphasize something else: it offers, to both CEOs and their Wall Street counterparts, an unending stream of consequential decisions taken under conditions of asymmetric information and uncertainty.

\subsection{The Great Compression}

One can accept that the effect of technologies on agency problems is institutionally contingent, and still hold that technology (or what Marx called the forces of production) is crucial. A given technological endowment may render certain institutional equilibria unstable (or, in Marx's language, utopian). To clarify this point it is useful to consider the role of earlier generations of technology in the period sometimes called the "great compression". Between 1942 and 1980, dispersion of wages and the income shares of the top 1 or $.01 \%$ both were low compared with the periods before and since.

One technologically-driven explanation for the compression is that relatively slow technological change - or, more precisely, a slow advance in capital-skill complementarity - together with the continued improvement of access to higher education, allowed the supply of skills to advance along with demand, so that the return to education remained low (Goldin and Katz 1998, 2008). The main role of institutions and politics in this argument is in determining the level of public investment in education, and there is nothing in the argument to suggest that particular technological regimes would do more or 
less to encourage this. Although in principle skill biases could be important, we do not find these explanations convincing.

Other explanations see the compression of earnings as institutionally constrained, rather than simply the outcome of changes in the supply and demand for skill. The list of institutions strengthened (or originated) at the dawn of the Great Compression is pretty much the same as those that neo-liberalism from ca. 1980 weakened (or abolished): protection of collective bargaining rights and, as a consequence, powerful unions; progressive taxation; regulation of banking and financial markets; price- or rate of return regulation of network industries; the common carrier principle in transport and communications; unemployment insurance; the minimum wage. Together with Keynesian fiscal and monetary policy, such measures constituted the regulatory framework of the Great Compression.

We can see the regulatory system of the Great Compression in the same way as the (absent) regulatory regime of our own time - that is, as a means of pulling in the tails of whatever income distribution would have been created by unregulated markets and unconstrained monopoly. In this case, the emblematic technologies are those associated with mass production; in recognition both of Ford's five dollar day and of the emblematic consumer good of the period, this is often known as Fordism (Piore and Sabel 1984; Marglin and Schor 1990; Aglietta 2001), a deal sealed at the "treaty of Detroit" (Levy and Temin 2007).

In earlier work we have argued that the technologies of the Fordist era were essential to unionization and, in turn, that unionization was essential both to redistribution at the level of the firm or industry and to the political coalition that backed the larger institutional package of the Great Compression (Guy and Skott 2008). The technologies in question are, again, ICTs, in this case the likes of the telegraph, the telephone, and the tabulating machine. Such technologies made it feasible to coordinate an elaborate, planned division of labor involving hundreds of thousands of employees in big corporations. The rigid bureaucratic structures for which the mid twentieth century was known were a reflection of both the capabilities and the limitations of the ICTs of the day. Economies of scale, scope, and speed offered substantial productivity benefits to large managerial firms; realization of these productivity gains was contingent on solving problems of coordination and control, and the limitations of the information systems necessitated a relatively rigid, single-path flow of materials and information. As result, in 1937 workers at General Motors were able to bring a large part of the operations of the company and many of its suppliers to a halt by sitting down in a few factories. Similarly, with telephone networks, the 
limited number of paths empowered operators -- who instead of sitting down went on strike by standing up - at the same time, across the country.

The rigidity of the production systems gave small groups of workers the ability to disrupt production and strengthened their bargaining power, and the flip side of organizational inflexibility was a reduction in top managers' scope for action which limited their agency rents. These factors reduced inequality even in a decentralized system of wage determination. Moreover, they provided a setting for industrial conflict which many saw as sometimes threatening the profitability of particular companies, or even the larger social order. Labor unions and government regulation offered a way to alleviate these threats and promote orderly industrial relations. Thus, the limitations of ICT facilitated the institutional changes that contributed to the great compression. ${ }^{6}$ By the same token, one important factor in Fordism's decline was the failure of the regulatory structure to keep pace with the application of new technologies. The various elements of the coalition that had put the regulations in place could not be re-united to renew them - the then-powerful Teamsters' union backed the arch-deregulator Reagan, for instance, because he chose a more moderate position on trucking deregulation than Carter - and the neo-liberal program of general deregulation prevailed.

A technological basis for the onset of the great compression could help make sense of the fact that something similar seems to have occurred at about the same time in many different countries -within antagonists on both sides of World War II (the US, UK, France, Japan) and in neutral countries both fascist and social democratic (Spain, Sweden) (Piketty and Saez 2007). Yet, these collapses in the income share of the top $1 \%$ are so close together in time that it is not really plausible to see them as independent national responses to technological changes: even if such responses were entirely mechanistic (which surely, they are not), the countries in question were at different levels of development. Whatever assistance there may have been from the technological quarter, we must also be looking at some sort of policy contagion. Moreover, it should be acknowledged that it can be easy, in

\footnotetext{
${ }^{6}$ The limited ICTs of the Fordist era would also have made for a stronger union voice effect (Freeman and Medoff 1984). If limited coordination technology forces a firm to rely on relatively inflexible rules, the firm can be brought to a standstill by its employees "working to rule". In this situation, doing a good job will sometimes require working beyond - and perhaps even in violation of - the rules, and employees therefore expose themselves to arbitrary retaliation from supervisors simply by doing a good job. In these cases unions may help ensure fair treatment, and as a result, unionized companies may gain productivity benefits. If improved ICTs mean an improved set of instructions for workers (i.e., improved rules), the value of union voice is diminished.
} 
hindsight to identify characteristics of an era's production organization that seem to have facilitated the institutional changes that followed.

The limits of technological determinism are illustrated by the diversity of international experience today. Increases in inequality and CEO pay are widespread, but vary considerably in magnitude. Looking ahead, it is hard to say whether policy adjustments similar to those of the great compression are feasible with today's technological endowment; eighty years ago, at the start of 1933, it was not clear either that a regulatory framework like that of the Great Compression was feasible.

\section{CEO pay}

Winner-take-all markets are often understood to have an effect on a market for talent; when taught, they are usually illustrated with examples from sports or the arts. Even if we accept the talent explanation in the case of those examples (we might not: Watts (2011) finds a large element of luck and path-dependence in the relative popularity of songs), there is little if any information asymmetry in our judgment of the value of the performance of a basketball player or singer: we like what we like, de gustibus. Many aspects of the work of executives, on the other hand, entail substantial information asymmetries.

Some managerial activities relate to the efficient production of the chosen output; anything from organizing an efficient production line to payroll administration. By contrast to these operational activities, portfolio decisions determine what should be produced, where it should be produced, and how and where it should be sold. Collecting and analyzing information to decide pricing strategies, the direction of new R\&D, the design of new products, the location of new factories, possible mergers, outsourcing, or changes in financing -- none of this has anything to do with the technical transformation of inputs into output. Managerial time spent on decision making of this kind is neither a substitute for direct production inputs -- allocating more resources to making the right pricing decisions does not reduce the input requirements per output unit -- nor a complement to production in any technical sense: the efficient production of a given amount of widgets does not require that prices be set at the profit maximizing level. In practice operational and portfolio activities overlap but conceptually the distinction is important: top management is primarily engaged in portfolio activities and these have no place in a standard production function. The activities are needed because making the right ('profit maximizing') decisions is no trivial matter; they reflect the difficulty of rational choice in an uncertain 
environment and the important consequences for the firm -- for better or worse -- of the choices that are being made.

As outlined in sections 2-3, new ICT in combination with regulatory and institutional changes have increased the range of portfolio options; the portfolio aspect of managerial activity has become increasingly dominant. ${ }^{7}$ These activities differ from the tasks of most production workers in at least two ways: ${ }^{8}$

-- the indivisibility of the discrete managerial decision and the uncertainty surrounding the effects of the decision (and the counterfactual)

-- the skills required to perform the task.

A skill based approach highlights the second element, suggesting that new technology has shifted the production function and raised the marginal product of the high-skill managerial input. But as suggested by the first element, unpredictable elements play an important part in determining success. Moreover, the fact that skill is involved does not prove that CEOs are uniquely skillful or even that it is the skill that is being rewarded. It is not clear that the existing managers are manifestly more skillful than other potential candidates. ${ }^{9}$ The agency problem suggests that high compensation may persist even if owners can choose from a pool of potential managers, all with exactly the same skills; high pay may depend more on non-skill elements. In fact, as we shall argue, an increased sensitivity of profits to managerial input could lead to a reduction in pay.

7 This has been an ongoing process. As noted by Auerbach and Skott (1988, pp. 46--47), a "modern firm, swelling with profits, does not, like Andrew Carnegie, simply build another steel mill ... The modern multinational makes it 'cost minimization' calculations not, as firms did in former times with consideration of local wage rates, but on a world-wide basis: by these standards former ' rational calculations' seem downright primitive".

${ }^{8}$ Consider the auto industry as an example. A shop-floor worker may be putting in (operating a robot that puts in) 10.000 dashboards over some period. A high level manager may spend the same period of time gathering and reviewing information leading to decisions about relocating production to Mexico, putting a billion dollars into developing an electric car, or entering a strategic alliance with a rival manufacturer.

${ }^{9}$ Commenting on the hearings of the Financial Crisis Inquiry Commission, Krugman (NYT 1/14/2010) observed: "Well, if you were hoping for a Perry Mason moment --- a scene in which the witness blurts out: Yes! I admit it! I did it! And I'm glad! --- the hearing was disappointing. What you got, instead, was witnesses blurting out: Yes! I admit it! I'm clueless! [it was] startling to hear Mr. Dimon admit that his bank never even considered the possibility of a large decline in home prices, despite widespread warnings that we were in the midst of a monstrous housing bubble." 


\subsection{Model}

If the function of top managers is intrinsically -- and increasingly -- linked with uncertainty about the properties of the world in which the firms are operating, the derivation of an 'optimal, profit maximizing managerial pay' becomes questionable (a well-defined optimal pay only exists if most of what a CEO does would not be needed in the first place). Still, it may be possible to outline how changes in the firm's environment can influence pay in a stylized model with stochastic elements as a proxy for uncertainty.

For simplicity disregard operational inputs (assume that these are chosen efficiently or alternatively, with a given level of competence) and focus on the portfolio activities -- pricing, investment, R\&D, financing etc. -- that lie behind standard assumption of 'profit maximization'. The firm's profits before managerial pay depend on these decisions, and we write the profits as the sum of two terms,

$$
\Pi=f(e ; \mu, A)+\lambda \varepsilon
$$

We focus on CEO pay and assume a single manager. The first term in $f$ relates profits to the CEO's 'effort' ( $e$ ). As in efficiency wage models generally, effort should be seen as a shorthand for acting diligently and in the best interest of the principal. Thus, effort includes not just putting in the effort that allows sensible decisions to be made but also the making of the 'right' decisions, given the evidence, as opposed to skewing decisions in ways that favor managers at the expense of owners -- whether by wasteful expenditures on corporate jets or the manipulation of indicators that determine managerial remuneration. The parameters $\mu$ and $A$ determine the shape and position of the $f$-function: an increase in $\mu$ raises the sensitivity of profits to managerial effort; an increase in $A$ produces an upward shift in the profit function. The second term is a random shock; $\varepsilon$ is a stochastic variable with mean zero and variance $\sigma^{2}$; an increase in the parameter $\lambda$ corresponds to a more risky environment.

New ICT and associated regulatory and institutional changes have affected the parameters $A, \mu, \lambda$ : options to outsource, for instance, and the effects of this option on domestic wages have provided new sources of cheap labor and raised profits for any given managerial effort; the emergence of a range of 
new options have increased the sensitivity of the outcome to l effort; a less stable and more uncertain business environment have increased both the sensitivity of profits to effort and the variance of the firm-specific random component.

These changes and their effects can be formalized using a modified Shapiro-Stiglitz model. CEOs are hired from a pool of identical candidates; both the number of CEO positions and the size of the pool of potential CEO candidates are taken as constant. A CEO either provides low effort (shirks) or high effort. The corresponding profits in period $t$ are

$$
\Pi_{t}=\begin{aligned}
& A+\mu+\lambda \varepsilon_{t} \quad \text { with high effort } \\
& A-\mu+\lambda \varepsilon_{t} \quad \text { with low effort }
\end{aligned}
$$

The CEO's performance is evaluated at the end of each period. Effort cannot be monitored directly; the evaluation is based entirely on the observable variable, $\Pi_{t}$. The CEO is fired if $\Pi_{t}$ falls below a threshold $M$. The value of $M$ determines the firing rates for both non-shirking and shirking CEOs.

A CEO maximizes

$$
E\left\{\sum_{0}^{\infty}(1-\rho)^{t} u_{t}\right\}
$$

where

$$
\begin{array}{cl}
w-v & \text { if holding a CEO position and providing high effort } \\
u_{t}=w & \text { if holding a CEO position and providing low effort } \\
b & \text { if "unemployed" }
\end{array}
$$

The utility $b$ from being unemployed (having a non-CEO position) and the disutility $v$ of supplying high effort are exogenously given in this version of the model; $\rho$ is the discount rate.

Standard derivations (see Appendix A) give the following no-shirking condition:

$$
w=b+\left[1+\frac{\rho+(1-\rho)(\delta+q)}{(1-\rho) p}\right] v
$$

where $\delta$ is the separation rate for non-shirkers, $p$ the firing rate associated with shirking, and $q$ the hiring rate for currently unemployed managers. The separation rate for non-shirkers has two 
components: an autonomous rate $\delta_{0}$ and a performance related component; depending on the threshold $M$, unlucky, non-shirking CEOs may be fired.

The hiring rate $q$ is exogenous to a single firm; the values of $\delta$ and $p$, by contrast, are determined by the firm's firing threshold, $M$. The values of $M$ and $w$ are set to maximize profits net of CEO compensation:

$$
\max E \Pi-w
$$

s.t.

$$
E \Pi=\begin{array}{ll}
A+\mu & \text { if } w \geq b+\left[1+\frac{\rho+(1-\rho)(\delta+q)}{(1-\rho) p}\right] v \\
A-\mu & \text { otherwise }
\end{array}
$$

We assume that $\varepsilon$ follows a uniform distribution on the interval $[-1,1]$,

$$
\varepsilon \sim R(-1,1)
$$

Given this assumption and the firing condition, we have (see appendix B and Figure 1),

$$
\begin{aligned}
& 1 \quad \text { if } \frac{M-A-\mu}{\lambda} \geq 1 \\
& \delta=\begin{array}{ll}
\delta_{0}+\left(1-\delta_{0}\right)\left(\frac{1}{2}+\frac{1}{2} \frac{M-A-\mu}{\lambda}\right) & \text { if } 1>\frac{M-A-\mu}{\lambda}>-1 \\
\delta_{0} & \text { if }-1 \geq \frac{M-A-\mu}{\lambda}
\end{array} \\
& 1 \quad \text { if } \frac{M-A+\mu}{\lambda}>1 \\
& p+\delta=\delta_{0}+\left(1-\delta_{0}\right)\left(\frac{1}{2}+\frac{1}{2} \frac{M-A+\mu}{\lambda}\right) \text { if } 1>\frac{M-A+\mu}{\lambda}>-1 \\
& \delta_{0} \quad \text { if }-1>\frac{M-A+\mu}{\lambda}
\end{aligned}
$$

Consider now the constrained profit maximization when the no-shirking condition is binding. The values of $p$ and $\delta$ are fully determined by $M$, and the wage is a function of $p$ and $\delta$. Tedious calculations show that the optimal value of $M$ is given by

$$
M^{*}=A+\mu-\lambda
$$

The intuition behind equation (10) is straightforward. An increase in the firing rate for CEO's that do not shirk raises the effective discount rate and dilutes the incentive to provide effort. Thus, the increase 
could only be justified if it hurt shirkers more than non-shirkers; with a uniform distribution of the shock, however, non-shirkers will be hurt at least as much as shirkers by an increase in $M$ above the expression for $M^{*}$ in (10)). It follows that $M^{*}$ cannot be greater than the expression in equation (10). On the other hand, shirkers should be punished if it can be done without hurting the non-shirkers; $M^{*}$ therefore cannot be less than the expression in (10)).

Combining equations (8)-(10), we get solutions for $\delta, p$ and $q$ :

$$
\begin{aligned}
& \delta=\delta_{0} \\
& p=\left(1-\delta_{0}\right) \min \left\{1, \frac{\mu}{\lambda}\right\}
\end{aligned}
$$

In a steady state the flows into and out of employment are equal,

$$
q=\delta_{0} \frac{n}{1-n}=\theta \delta_{0}
$$

where $n$ is the employment rate for CEOs. By assumption the number of CEOs and the pool of potential candidates are constant; thus, the employment rate $n$ and $\theta=n /(1-n)$ are constant too.

Plugging the solutions for $p, \delta$ and $q$ into the expressions for $w$ and $E \Pi-w$, we get

$$
\begin{aligned}
& w^{\text {no-shirk }}=b+\left[1+\frac{\rho+(1-\rho) \delta_{0}(1+\theta)}{(1-\rho)\left(1-\delta_{0}\right) \min \left\{1, \frac{\mu}{\lambda}\right\}}\right] v \\
& E \Pi^{\text {no-shirk }}-w^{\text {no-shirk }} \\
& =A+\mu-b-\left[1+\frac{\rho+(1-\rho) \delta_{0}(1+\theta)}{(1-\rho)\left(1-\delta_{0}\right) \min \left\{1, \frac{\mu}{\lambda}\right\}}\right] v
\end{aligned}
$$

The expression in (15) has to be compared with the profits that are obtained when the no-shirking condition does not hold and the CEO is paid the reservation wage, $b$ :

$$
E \Pi^{\text {shirk }}-b=A-\mu-b
$$

The firm will want to pay the high, no-shirking wage if

$$
\begin{aligned}
& E \Pi^{\text {no-shirk }}-w^{\text {no-shirk }}-\left(E \Pi^{\text {shirk }}-b\right) \\
= & 2 \mu-\left[1+\frac{\rho+(1-\rho) \delta_{0}(1+\theta)}{(1-\rho)\left(1-\delta_{0}\right) \min \left\{1, \frac{\mu}{\lambda}\right\}}\right] v>0
\end{aligned}
$$

This condition is satisfied if $\mu$ is sufficiently large, that is, if profits before CEO pay are sufficiently 
sensitive to CEO effort. We assume that the condition is met; without the condition, the agency problem becomes uninteresting.

We are left with two cases (see Figure 2). If $\lambda<\mu$, the range of possible profits under a shirking manager does not overlap with the range of profits under a non-shirking manager. Loosely speaking, the degree of uncertainty is small relative to the sensitivity of profits to managerial effort. As a result, realized profits fully reveal whether the manager has been shirking and marginal variations in $A, \mu$ and $\lambda$ have no effect on managerial pay.

The more interesting case arises when uncertainty is high and $\lambda>\mu$. In this case, it follows from equation (14) that:

- an increase in $A$ has no effect on CEO pay

- $\quad$ an increase in $\mu$ reduces CEO compensation and raises profits. The reason is simple. A higher sensitivity makes it easier to determine whether the CEO is shirking; the agency problem is alleviated.

- $\quad$ an increase in $\lambda$ raises CEO compensation and reduces profits.

- a proportional increase in $\mu$ and $\lambda$ leaves CEO compensation unchanged and enhances profits net of CEO compensation.

\section{2 An extension: fairness and changes in reference groups}

Efficiency-wage arguments can be cast in different ways. In section 4.1 we deliberately chose a version that is standard in the literature and that also seems to fit traditional Marxian notions of labor discipline. Formulations that emphasize fairness and reciprocity, however, may have more empirical support than the Shapiro-Stiglitz version. Akerlof and Yellen (1990) introduced fairness norms as a basis for efficiency wage models, and the survey evidence reported by Bewley (1999) strongly supports this approach.

The fair wage is influenced by market conditions and in the Shapiro-Stiglitz framework market conditions are represented by the risk and cost of job loss; the fairness element can be captured by letting the disutility $v$ reflect the prevailing norms. The interpretation is straightforward. The disutility of providing effort that benefits someone else depends on one's feelings towards that someone; if the 
owners have been treating the CEO well, the disutility will be low. ${ }^{10}$

Formally, let

$$
v=\phi\left(\frac{w}{w_{a}}, \gamma\right) ; \quad \phi_{w}<0, \phi_{\gamma}>0
$$

where $w_{a}$ is a reference wage and $\gamma$ represents a shift variable. The shift variable $\gamma$ in equation (18) is a catch-all for other factors that influence pay norms, including the general ideological climate; the Reagan-Thatcher years, for instance, heralded a shift in attitudes on issues ranging from inequality to the limits on socially acceptable greed and self-promotion.

There is widespread evidence that fairness is determined by relative wages rather than absolute wages. Thus, we assume that $\varphi_{w}<0$; that is, the disutility $v$ falls and, reciprocating an increase in the relative wage, the CEO is motivated to raise effort. It seems reasonable to suppose that the reference wage $w_{a}$ contains (at least) two elements: the average wage paid to other CEOs $(\bar{w})$ and the average wage paid to the firm's production workers $(Z)$. As a simple formalization, the reference wage can be written as a weighted average,

$$
w_{a}=\alpha \bar{w}+(1-\alpha) z
$$

The composition of the reference group may change; specifically, the value of $\alpha$ may have increased. Evidence of this shift can be found in the increasing-- and increasingly formalized -- weight of CEOs of comparable companies in compensation committees' decisions (Elson and Ferrere (2012)). ${ }^{11}$

The implications of an increase in $\alpha$ follow directly from equations (14), (18)-(19). Substituting (18)(19) into (14), using the equilibrium condition $w=\bar{w}$, and taking total derivatives, we get

${ }^{10}$ Neither the steady-state assumption nor the full intertemporal optimizationin section 4.1 fit well with a normbased approach. But fairness norms and reciprocity may produce a reduced-form equation of the same form as (14); that is,

$$
w=b+B v
$$

with $B=B\left(\frac{\lambda}{\mu}\right), B^{\prime}>0$.

${ }^{11}$ The shifting weights are not surprising. The volatility of firm level outcomes raises the cost of attachment to employees; paying CEOs as if they were capitalists helps increase social separation between them and their subordinates, and increases identification (as well as incentive alignment) with their principals. 


$$
\frac{d w}{d \alpha}=\frac{-B \phi^{\prime} \frac{w(w-z)}{[\alpha w+(1-\alpha) z]^{2}}}{1-B \phi^{\prime} \frac{(1-\alpha) z}{[\alpha w+(1-\alpha) z]^{2}}}>0
$$

where $B=1+\frac{\rho+(1-\rho) \delta_{0}(1+\theta)}{(1-\rho)\left(1-\delta_{0}\right) \min \left\{1, \frac{\mu}{\lambda}\right\}}$. The numerator is positive (the reference wage is increasing in $\alpha$ (equation 19); an increase in the reference wage raises the disutility of effort, for given $w$ (equation 18); an increase in the disutilty $v$ raises the wage $w)$; the denominator is greater than one, reflecting the dampening effects of a rise in $w$ on the disutilty of effort. The net effect of the shift in the composition of the reference group is a rise in executive pay. Analogously, we have $d w / d y>0$.

Shifts in pay norms - whatever the sources of the shift - can be a direct, non-market influence on the evolution of CEO pay in this model; an increase in pay to the CEO is matched by a decline in net profits to owners without any necessary, derived effects on the firm's strategy or relative factor inputs. Thus, our analysis supports the emphasis on institutional and ideological factors (e.g. Atkinson 1998, Levy and Temin 2007, Piketty and Saez (2003), Mishel et al. 2012, Elson and Ferrere 2012). Non-market forces are brought in to determine distribution.

A similar indeterminacy in the division of gross profits arises in matching models with match-specific rents. The indeterminacy in this alternative setting can be resolved by assigning 'bargaining power' to the two parties and using a Nash bargaining model. As in the efficiency wage setting, the outcome depends on power, and in many respects the conclusions from the two models may be similar. The advantage of the efficiency wage version, in our view, is that it highlights the agency problem and directs attention to factors that determine relative power; increasing uncertainty (volatility), for instance. Even when it comes to norm-based effects, the agency setting provides a clearer and in our view more convincing story. CEOs gain power from their ability and willingness to hurt the interests of the owners; a change in pay norms has a direct effect on pay because it influences the willingness. ${ }^{12}$ Putting it differently, if CEOs feel badly treated at pay rates below $\$ 10$ million, this fact forces firms to pay up. ${ }^{13}$ This fairness perspective is implicit in Elson and Ferrere's (2012) account of boards and

\footnotetext{
12 In economics, the strategic role of emotions has been stressed by Frank (1988).

13 The correlation between firm size and CEO pay, according to this perspective, may owe as much to the widespread view that pay ought to be related to size and CEO responsibility as it does to more objective differences in the severity of the agency problem.
} 
compensation committees' choice of median (or above median) pay as the target: ${ }^{14}$

"If a board were to award lower than expected pay by compensating below median (market), it is understandable that there may be psychological consequences as a result of perceived inequitable treatment ... Theories of pay equity suggest that when paid less than one's peers, a person may seek redress through the withdrawal of effort." (pp. 38-39)

\subsection{Limitations}

The models in sections 4.1-4.2 have obvious limitations. Uncertainty was replaced with a simple stochastic element; the dichotomy between low and high effort is attractive mainly because of its analytical tractability; the Shapiro-Stiglitz version of the model focused on steady-states with constant values $V$ and $U$; it was assumed that firms have full knowledge of the various parameters underlying the choice of effort. ${ }^{15}$ These simplifications make the analysis tractable and do not, we believe, distort the basic argument: increasing uncertainty and changing social norms have exacerbated the agency problem and contributed strongly to the explosion in executive pay.

A more serious objection may focus on the absence of performance related pay in the model. We took managerial pay to be a simple wage $w$. Stock options and other performance related remuneration packages clearly play a role in executive pay. We have ignored this element for several reasons. The incentive effects of these packages, first, will be partly offset by golden handshakes. Performance pay, second, may be less important than often believed; according to Tosi et al. (2000), performance explains less than five percent of executive pay. The incentives, third, bring their own

${ }^{14}$ The effect arises even in the absence of executive capture of compensation committees and company boards.

${ }^{15}$ We also disregarded the endogenous element in the formation of norms: fairness norms adjust over time in response to actual achievements. According to Kahneman et al. (1986, p. 730-1)

"any stable state of affairs tends to become accepted eventually, at least in the sense that alternatives to it no longer readily come to mind. Terms of exchange that are initially seen as unfair may in time acquire the status of reference transaction. Thus, the gap between the behaviour that people consider fair and the behavior that they expect in the market-place tends to be rather small."

Skott (2005) includes endogenously changing pay norms in a model with two types of workers. Atkinson (1998, p. 19) also notes the endogeneity, arguing that

"As more people are remunerated outside the conventional norms, so adherence to these norms becomes weaker, and the socially acceptable range of remuneration becomes wider." 
distortions as managers strive to augment the particular performance indicators that determine their pay; the distortions may include a focus on short-term profits (or immediate stock market gains) at the expense of long-term investment.

\section{Conclusions}

Skill-biased shifts are commonly used to explain the trends in inequality and sky-rocketing CEO pay, in particular (e.g. Murphy and Zábojník 2004; Garicano and Rossi-Hansberg 2006; Gabaix and Landier 2008). The details differ but the essential element is that pay has increased because changes associated with new ICT have made profits increasingly sensitive to variations in the quality of the managerial input and/or have raised the reservation wage of high-skill managers. We find these skill-based explanations incomplete, at best. In corporate governance contexts the use of agency models is a standard way of modeling CEO pay, for good reason; the impact of new technologies is best approached by understanding how these technologies, and the consequent changes in market structure, affect the agency problems.

The new technologies have accentuated the information asymmetry between managers and shareholders. But there is an institutional context: WTA markets, which led to greater sensitivity of profit to managerial effort; the uncertainty in the mapping of observed profit outcomes onto managerial effort; the norms and social comparisons which mediate the manager's response to different pay outcomes - are all institutionally constrained. The international diversity in levels and changes in inequality testifies to the importance of this institutional contingency. 


\section{Appendix A: Derivation of the no-shirking wage and expected profits}

A manager maximizes

$E\left\{\sum_{0}^{\infty}(1-\rho)^{t} u_{t}\right\}$

where

$w-v$ if holding a CEO position and providing high effort

$u_{t}=w \quad$ if holding a CEO position and providing low effort

b if "unemployed"

The utility $b$ from being unemployed (having a non-CEO position) and the disutility $v$ of supplying high effort are exogenously given; $\rho$ is the discount rate.

The value functions for employed CEOs satisfy

$$
\begin{aligned}
& V_{E}=w-v+(1-\rho)\left[(1-\delta) V_{E}+\delta U\right] \\
& V_{S}=w+(1-\rho)\left[(1-\delta) V_{S}+\delta U\right]
\end{aligned}
$$

where $V_{E}$ and $V_{S}$ are the value functions for managers with high and low effort, and $U$ the value function for an unemployed manager. The no-shirking condition requires that $V_{E}=V_{S}=V$, and $U$ is given by

$$
U=b+(1-\rho)[q V-(1-q) U]
$$

Using (A2)-(A3) we get

$$
\begin{aligned}
& \rho V=w-v+(1-\rho) \delta[U-V] \\
& \rho V=w+(1-\rho)(\delta+p)[U-V] \\
& \rho U=b+(1-\rho) q[V-U]
\end{aligned}
$$

Subtracting (A5) from (A4),

$$
V-U=\frac{v}{(1-\rho) p}
$$

and, using (A4) and (A6), 


$$
\rho(V-U)=w-v-b-(1-\rho)(\delta+q)[V-U]
$$

Hence,

$$
w=v+b+\frac{\rho+(1-\rho)(\delta+q)}{(1-\rho) p} v=b+\left[1+\frac{\rho+(1-\rho)(\delta+q)}{(1-\rho) p}\right] v
$$

The flows into and out of employment are equal in a steady state. Wages are set to satisfy the noshirking condition, the outflow is given by $\delta$, and it follows that

$$
q(1-n)=\delta n
$$

where $n$ is the employment rate. By assumption both the number of CEOs and the size of the pool of potential managers are constant; $n$ therefore is also constant. Letting

$$
\theta=\frac{n}{1-n}
$$

the wage equation can be written

$$
w=b+\left[1+\frac{\rho+(1-\rho) \delta(1+\theta)}{(1-\rho) p}\right] v
$$

\section{Appendix B: Choice of firing threshold}

From (A12) it follows that $M$ should be chosen to minimize the ratio

$$
\frac{\rho+(1-\rho) q+(1-\rho) \delta}{(1-\rho) p}
$$

The values of $\rho$ and $q$ are exogenous to the firm; the separation rates $\delta$ and $(\delta+p)$ for high and low effort managers are determined by $M$. Using (8)-(9) -- see also figure 12 -- we get

$$
\frac{\partial(\delta+p)}{\partial M}=\frac{\partial \delta}{\partial M}>0, \frac{\partial p}{\partial M}=0 \text { if } A+\mu+\lambda>M>A+\mu-\lambda
$$




$$
\frac{\partial(\delta+p)}{\partial M}>0, \frac{\partial \delta}{\partial M}=0, \frac{\partial p}{\partial M}>0 \text { if } A+\mu-\lambda>M>A-\mu-\lambda
$$

From (B2) it follows that the optimal $M$ cannot exceed $A+\mu-\lambda$; from (B3) it follows that the optimal $M$ cannot be less than $A+\mu-\lambda$. 


\section{References}

Aglietta, Michel. 2001. A Theory of Capitalist Regulation: the US Experience. Translated by D. Fernbach. London: Verso. Original edition, 1979.

Akerlof, G.A. and Yellen, J.L. (1990)"The fair wage-effort hypothesis and unemployment". Quarterly Journal of Economics, 105, pp. 254-283.

Atkinson, A.B.(1998) "The distribution of income in industrialized countries". In: Income Inequality Issues and Policy Options. Federal Reserve Bank of Kansas City, pp. 11-32.

Atkinson, Anthony B. 2000. The Changing Distribution of Income: Evidence and Explanations. German Economic Review 1.

Auerbach, Paul, and Peter Skott. 1988. Concentration, Competition, and Distribution: A Critique of Theories of Monopoly Capital. International Review of Applied Economics 2 (1):42-61.

Autor, David H., Lawrence F. Katz, and Melissa S. Kearney. 2008. Trends in U.S. Wage Inequality: Revising the Revisionists. Review of Economics and Statistics 90 (2):300-323.

Bewley, T.F. (1999) Why Wages Don't Fall During a Recession. Cambridge, MA: Harvard University Press.

Boldrin, Michele, and David K Levine. 2008. Against Intellectual Monopoly. Cambridge: Cambridge University Press.

Brandt, Michael W., Alon Brav, John R. Graham, and Alok Kumar. 2010. The Idiosyncratic Volatility Puzzle: Time Trend or Speculative Episodes? Review of Financial Studies 23 (2):863-899.

Campbell, John Y., Martin Lettau, Burton G. Malkiel, and Xu Yexiao. 2001. Have Individual Stocks Become More Volatile? An Empirical Exploration of Idiosyncratic Risk. Journal of Finance 56 (1):1-43.

Card, David, and John E. DiNardo. 2002. Skill-Biased Technological Change and Rising Wage Inequality: Some Problems and Puzzles. Journal of Labor Economics 20 (4):733.

Card, David, Jörg Heining, and Patrick Kline. 2012. Workplace Heterogeneity and the Rise of West German Wage Inequality. National Bureau of Economic Research Working Paper Series No. 18522.

Chun, Hyunbae, Jung-Wook Kim, and Randall Morck. 2010. Varying Heterogeneity among U.S. Firms: Facts and Implications. Review of Economics and Statistics 93 (3):1034-1052.

Chun, Hyunbae, Jung-Wook Kim, Randall Morck, and Bernard Yeung. (2008). "Creative destruction and firm-specific performance heterogeneity". Journal of Financial Economics 89 (1):109-135.

Comin, Diego A., Mark Gertler, and Ana Maria Santacreu. 2009. Technology Innovation and Diffusion as Sources of Output and Asset Price Fluctuations. National Bureau of Economic Research, Inc.

Comin, Diego, William Easterly, and Erick Gong. 2010. Was the Wealth of Nations Determined in 1000 BC? American Economic Journal: Macroeconomics 2:65-97.

Comin, Diego, and Sunil Mulani. (2006). "Diverging trends in aggregate and firm volatility". Review of Economics and Statistics 88 (2):374-383.

DiNardo, John, Nicole M. Fortin, and Thomas Lemieux. 1996. Labor Market Institutions and the Distribution of Wages, 1973-1992: A Semiparametric Approach. Econometrica 64 (5):1001-44.

Elson, Charles M. and Ferrere, Craig K. (2012) “Executive Superstars, Peer Groups and Over- 
Compensation - Cause, Effect and Solution" . Available at SSRN: http://ssrn.com/abstract=2125979 or http://dx.doi.org/10.2139/ssrn.2125979

Frank, Robert. (1985). Choosing the Right Pond. New York: Oxford University Press.

Frank, Robert. (1988) Passions Within Reason: The Strategic Role of Emotions. New York: W.W. Norton.

Freeman, Richard B, and James L. Medoff. 1984. What do Unions Do? New York: Basic Books.

Gabaix, X. and Landier, A. (2008) "Why Has CEO Pay Increased So Much?". The Quarterly Journal of Economics, 123(1), pp. 49-100.

Garicano, Luis, and Esteban Rossi-Hansberg (2006) Organization and Inequality in a Knowledge Economy. Quarterly Journal of Economics, CXXI, pp. 1383-1435.

Goldin, Claudia, and Lawrence F. Katz. 1998. The Origins of Technology-Skill Complementarity. Quarterly Journal of Economics 113 (3).

Goldin, Claudia, and Lawrence F. Katz. 2008. The Race Between Education and Technology. Cambridge, Massachusetts: Harvard University Press.

Gourevitch, Peter A, and James Shinn. 2005. Political Power and Corporate Control: The New Global Politics of Corporate Governance. Princeton, N.J.: Princeton University Press.

Guy, Frederick. 2005. Earnings Distribution, Corporate Governance and CEO Pay. International Review of Applied Economics 19 (1):51-65.

Guy, Frederick, and Peter Skott. (2008). "Communications Technology and the Distribution of Income". Journal of Income Distribution 17 (3-4):71-92.

Guy, Frederick, and Peter Skott. (2008a). "Power, productivity, and profits". In Power, Freedom, and Voting, edited by M. Braham and F. Steffen. Heidelberg: Springer.

Hounshell, David A. 1984. From the American System to Mass Production, 1800-1932. Baltimore: Johns Hopkins University Press.

Jensen, Michael C. 1989. Eclipse of the public corporation. Harvard Business Review 67 (5):61-74.

Jensen, M.C. and Meckling, W.H. (1976) "Theory of the Firm: Managerial Behavior, Agency Costs and Ownership Structure". Journal of Financial Economics, 3(4), pp. 305-360.

Jensen, Michael C., and Kevin J. Murphy. 1990. Performance pay and top management incentives. Journal of Political Economy 98 (2):225-264.

Juhn, Chinhui, Kevin Murphy, and Brooks Pierce. 1993. Wage Inequality and the Rise in Returns to Skill. Journal of Political Economy 101 (3):410-442.

Kahneman, D. Knetsch, J.L., Thaler, R. (1986) "Fairness as a constraint on profit seeking: entitlements in the market". American Economic Review 76, pp. 728-741.

Kaplan, Steven N., and Joshua Rauh. 2010. Wall Street and Main Street: What Contributes to the Rise in the Highest Incomes? Review of Financial Studies 23 (3):1004-1050.

Kurzweil, Ray. 1992. The Age of Intelligent Machines. Cambridge, Mass: MIT Press.

Levy, Frank, and Peter Temin. 2007. Inequality and Institutions in 20th Century America. MIT. 
Marglin, Stephen A., and Juliet B. Schor, eds. 1990. The Golden Age of Capitalism. Oxford: Oxford University Press.

Minsky, Hyman P. 1975. John Maynard Keynes. New York: Columbia University Press.

Morck, Randall, Bernard Yeung, and Wayne Yu. (2000) "The information content of stock markets: why do emerging markets have synchronous stock price movements? Journal of Financial Economics 58 (1--2):215-260.

Murphy, Kevin J., and Jan Zabojnik (2004) CEO Pay and Appointments: A Market-based Explanation for Recent Trends. American Economic Review Papers and Proceedings, XCIV, pp. 192-196.

O'Sullivan, Mary. 2001. Contests for Corporate Control: Corporate Governance and Economic Performance in the United States and Germany Oxford: Oxford University Press.

Pástor, Ĺuboš, and Pietro Veronesi. 2009. Technological Revolutions and Stock Prices. American Economic Review 99 (4):1451-83.

Philippon, Thomas, and Ariell Reshef. 2008. Wages and Human Capital in the U.S. Financial Industry: 1909-2006. New York: New York University.

Piketty, Thomas, and Emmanuel Saez. 2003. Income Inequality in the United States, 1913-2002. Quarterly Journal of Economics 118 (1):1-39.

Piketty, Thomas, and Emmanuel Saez. 2007. Income Inequality in the United States: 1913-2002. In Top Incomes Over the Twentieth Century: A Contrast Between European and English-Speaking Countries. New York: Oxford University Press.

Piore, Michael J., and Charles Sabel. 1984. The second industril divide: possibilities for prosperity. New York: Basic Books.

Porter, Michael E. (1985). Competitive Advantage: Creating and Sustaining Superior Performance. New York: Academic Press.

Prahalad, C.K., and Gary Hamel. (1990). "The core competance of the corporation". Harvard Business Review 68 (3):79-91.

Raymond, Eric S. 1998. The cathedral and the bazaar.

Sell, Susan, and Christopher May. 2001. Moments in law: contestation and settlement in the history of intellectual property. Review of International Political Economy 8 (3):467-500.

Shapiro, C. and Stiglitz, J. (1984) "Equilibrium Unemployment as a Worker Discipline Device"..The American Economic Review, 74(3), pp. 433-444.

Simon, Herbert A. 1957. The compensation of executives. Sociometry 20:32-35.

Skott, Peter. (2005) Fairness as a Source of Hysteresis in Employment and Relative Wages. Journal of Economic Behavior and Organization, 57, pp. 305-331.

Skott, Peter, and Frederick Guy. (2007)."A Model of Power-Biased Technological Change". Economics Letters 95 (1):124-131.

Spence, Michael A, and Sandile Hlatshwayo. (2011). The Evolving Structure of the American Economy and the Employment Challenge. New York: Council on Foreign Relations.

Stallman, Richard. 1985. The GNU Manifesto. 
Sturgeon, Timothy J. (2002). "Modular production networks: a new American model of industrial organization". Industrial and Corporate Change 11 (3):451-496.

Tosi, H.L., Werner, S., Katz, J.P, and Gomez-Mejia, L.R. (2000) "How much does performance matter? A Meta-Analysis of CEO Pay Studies". Journal of Management,.26 (2), pp. 301-339.

von Braun, Christoph-Friedrich. 1990. The Acceleration Trap. Sloan Management Review 32 (1):49-58.

Watts, D.J (2011) Everything Is Obvious* (*Once You Know the Answer). New York: Crown Business.

Wei, Steven X., and Zhang Chu. 2006. Why Did Individual Stocks Become More Volatile? Journal of Business 79 (1):259-292. 